\title{
Hubungan Berat Badan Lahir Rendah dan Penyakit Infeksi dengan Kejadian Stunting pada Baduta di Desa Maron Kidul Kecamatan Maron Kabupaten Probolinggo
}

\section{The Relationship Between Low Birth Weight and Infection Disease with Stunting among Children Under Two Years of Age in at Maron Kidul Village Maron Subdistrict in Probolinggo District}

\author{
Novianti Tysmala Dewi*, Dhenok Widari ${ }^{1}$
}

\begin{abstract}
ABSTRAK
Latar Belakang: Stunting merupakan masalah gizi yang memiliki prevalensi tinggi di Indonesia. Stunting pada baduta memiliki risiko lebih tinggi jika dibanding dengan kelompok usia lain karena akan berdampak secara permanen terhadap perkembangan fisik dan kognitif anak dimasa depan. Faktor penyebab stunting diantaranya adalah berat badan lahir rendah dan penyakit infeksi.

Tujuan: Penelitian ini bertujuan untuk untuk menganalisis hubungan antara berat badan lahir rendah dan penyakit infeksi dengan kejadian stunting pada baduta di Desa Maron Kidul Kecamatan Maron, Kabupaten Probolinggo.

Metode: Jenis penelitian menggunakan desain case-control. Sampel diambil dengan teknik sampel acak bertahap. Penelitian dilakukan pada bulan Juni hingga Juli 2018. Besar sampel sebanyak 52 baduta (26 anak stunting dan 26 anak non-stunting). Pengumpulan data penyakit infeksi dilakukan dengan wawancara kuisioner terstruktur dan rekam medik sedangkan berat badan lahir rendah diperoleh dengan melihat buku KIA. Penentuan stunting baduta diperoleh melalui pengukuran panjang badan dengan metline. Data dianalisis menggunakan chi-square untuk menentukan odds ratio.

Hasil: Hasil penelitian menunjukkan ada hubungan berat badan lahir rendah $(p=0.042 ; O R=0,157 ; 95 \%$ $\mathrm{Cl}: 0,030-0,822)$, dan penyakit infeksi ( $p=0,049 ; \mathrm{OR}=3,071 ; 95 \% \mathrm{Cl}: 1,155-11,861)$ dengan kejadian stunting pada baduta.

Kesimpulan: Berat badan lahir rendah dan penyakit infeksi dalam 3 bulan terakhir meningkatkan risiko sebesar 0,157 dan 3,017 kali terhadap kejadian stunting pada baduta. Disarankan untuk baduta yang memiliki masalah BBLR dan penyakit infeksi diberikan perhatian khusus oleh posyandu serta perlu dilakukan peninjauan terkait perkembangan secara rutin agar gangguan perkembangan yang mungkin terjadi dapat segera dikenali dan diatasi.
\end{abstract}

Kata kunci: stunting, bblr, penyakit infeksi

\section{ABSTRACT}

Background: Stunting is a nutritional problem that has a high prevalence in Indonesia. Stunting among children under two years of age has a higher risk compared to other age groups because it will permanently affect the physical and cognitive development of children in the future. Factors that can cause stunting include low birth weight and infectious diseases. 
Objectives: The aim of this study was to determine the relationship between low birth weight and infection disease with incident of stunting among children under two years of age in Maron sub district, District of Probolinggo, East Java.

Methods: This research was an observational research with case-control design. Sampling technique using multistage random sampling. the study was conducted in June until July 2018. The samples of study were 52 children (26 stunted children in case group and 26 normal growth children in control group. Data collection of infectious diseases was carried out by structured questionnaire interviews and medical records while low birth weight was obtained by looking at KIA book. Stunting was determined from measurement of children's recumbent length by metline. Data were analyzed by using chi square test for determining odds ratio.

Results: The results showed that low birth weight ( $p=0.042 ; O R=0.157 ; 95 \% \mathrm{Cl}: 0.030-0.822)$ and infection disease ( $p=0.049$; OR=3.071; 95\% Cl: 1.155-11.861) had significant relation with stunting among children under two years of age.

Conclusions: Low birth weight and infection disease in the last 3 months increased the risk of 0.157 and 3.017 times stunting among children under two years of age. It is recommended for children under two years of age who have low birth weight and infectious disease should be given special attention by Integrated Health Post and there should be a monitoring related development routinely so developmental disruptions can be identified and immediately get the treatment.

Keywords: stunting, low birth weight, infection disease

*Koresponden:

novisnti2323@gmail.com

${ }^{1}$ Dinas Kesehatan Kota Surabaya Jawa Timur, Indonesia

\section{PENDAHULUAN}

Periode penting dalam tumbuh kembang anak yaitu pada masa baduta (bawah dua tahun). Baduta merupakan target program penyelamatan seribu hari pertama kehidupan. Seribu hari pertama kehidupan merupakan masa kritis yang menentukan masa depan baduta dan dapat mempengaruhi pertumbuhan dan perkembangan baduta ${ }^{1}$. Berdasarkan data di Indonesia prevalensi stunting yaitu sebesar 36,4\% dan menempati negara tertinggi ke 4 untuk angka stunting tertinggi di Asia².

Salah satu provinsi dengan prevalensi balita stunting yang cukup tinggi adalah Jawa Timur dengan total prevalensi balita pendek dan sangat pendek tahun 2015 sebesar 27,1\% ${ }^{3}$. Salah satu wilayah Kabupaten yang memiliki angka prevalensi stunting yang cukup tinggi yaitu Kabupaten Probolinggo. Kabupaten Probolinggo termasuk dalam kabupaten/kota prioritas untuk intervensi stunting dengan prevalensi stunting sebesar $49,43 \%$ pada tahun $2013^{4}$. Kecamatan Maron merupakan kecamatan yang memiliki kasus berat badan lahir rendah nomor 3 tertinggi di Probolinggo yaitu sebesar 8,67\%. Selain itu, Kecamatan Maron termasuk dalam 5 kecamatan dengan kasus stunting tertinggi di Probolinggo ${ }^{5}$. Untuk mencapai pertumbuhan dan perkembangan yang baik bagi baduta maka berat badan lahir dan penyakit infeksi merupakan faktor sangat penting untuk diperhatikan. Berat badan lahir anak dan penyakit infeksi memiliki dampak yang besar terhadap pertumbuhan dan perkembangan baduta selanjutnya ${ }^{6}$.

Penelitian menunjukkan bahwa bayi dengan BBLR memiliki risiko lebih besar untuk mengalami gangguan perkembangan dan pertumbuhan pada masa kanak - kanak. Anak sampai dengan usia 2 tahun dengan riwayat BBLR memiliki risiko mengalami gangguan pertumbuhan dan akan berlanjut pada 5 tahun pertama kehidupannya jika tidak diimbangi dengan pemberian stimulasi yang lebih ${ }^{7}$. Bayi prematur dan BBLR yang dapat bertahan hidup pada 2 tahun pertama kehidupannya memiliki risiko kurang gizi dan stunting ${ }^{8}$. Bayi dengan BBLR mengalami pertumbuhan dan perkembangan lebih lambat sejak dalam kandungan karena retardasi pertumbuhan intera uterin, hal ini dapat berlanjut hingga anak telah lahir jika tidak didukung dengan 
pemberian gizi dan poal asuh yang baik dimana akhirnya sering gagal mengejar tingkat pertumbuhan yang seharusnya dia capai pada usianya $^{9}$. Selain itu, anak dengan berat badan lahir rendah ( $<2500$ gram) akan berpeluang 3,03 kali lebih besar untuk mengalami stunting dibandingkan dengan yang memiliki berat badan normal ${ }^{10}$.

Stunting juga dapat terjadi akibat konsekuensi dari infeksi yang berulang sehingga memperburuk status gizi anak. Interaksi antara malnutrisi dan infeksi merupakan suatu keadaan timbal balik yang saling mempengaruhi. Malnutrisi dan infeksi dapat terjadi secara bersamaan. Infeksi dapat menyebabkan malnutrisi, sedangkan malnutrisi dapat meningkatkan risiko infeksi. Malnutrisi pada anak yang memiliki daya tahan tubuh lemah akan mudah jatuh sakit sehingga mengurangi kemampuannya untuk melawan penyakit dan terlambatnya pertumbuhan anak ${ }^{11}$.

Penyakit infeksi yang berisiko pada usia 2 tahun pertama terhadap kejadian stunting adalah penyakit diare dan ISPA. Selain itu, Berdasarkan data diketahui kejadian diare dan ISPA paling banyak terjadi pada balita menurut karakteristik kelompok umur. Anak yang mengalami gizi buruk memiliki risiko 9,5 kali lebih besar mengalami diare daripada anak yang tidak mengalami diare, dan anak yang stunting berisiko mengalami kematian 4,6 kali lebih besar ${ }^{12}$. Penelitian lain menyebutkan bahwa anak yang mengalami diare memiliki tinggi badan lebih pendek yaitu $0,38 \mathrm{~cm}$ dibandingkan anak yang tidak mengalami diare ${ }^{13}$.

Penyakit ISPA merupakan penyakit yang sangat sering dijumpai dan merupakan penyebab kematian paling tinggi pada anak balita. Frekuensi ISPA berhubungan dengan status gizi balita dimana semakin tinggi frekuensi ISPA maka status gizi balita semakin buruk ${ }^{14}$. Anak yang memiliki riwayat penyakit ISPA memiliki risiko 4 kali lebih besar untuk mengalami stunting dibandingkan dengan yang tidak mengalami penyakit ISPA ${ }^{15}$.

Tujuan penelitian ini adalah untuk menganalisis hubungan antara berat badan lahir rendah dan penyakit infeksi dengan kejadian stunting pada baduta di Desa Maron
Kidul Kecamatan Maron, Kabupaten Probolinggo.

\section{METODE}

Jenis penelitian yang digunakan adalah case-control. Penelitian ini dilakukan di Desa Maron Kidul Kecamatan Maron Kabupaten Probolinggo, yang dilakukan pada bulan JuniJuli 2018. Jumlah populasi baduta sebanyak 158 baduta. Besar sampel sebanyak 52 baduta (26 baduta stunting dan 26 baduta non stunting). Pada kelompok kontrol dilakukan matching tempat tinggal dan umur. Kelompok kasus merupakan baduta stunting, sedangkan kelompok kontrol yaitu baduta non stunting yang diambil dari 8 Posyandu di Desa Maron Kidul. Sampel diambil dengan teknik simple acak bertahap (multistage random sampling). Pengambilan pertama dilakukan dengan teknik acak proporsional (proportional random sampling), dilakukan perhitungan untuk menentukan jumlah baduta di 8 Posyandu Desa Maron Kidul. Setelah itu, dilakukan teknik acak sederhana yaitu dengan cara mengundi. Variabel independen dalam penelitian ini adalah usia, jenis kelamin, pekerjaan, pendidikan, pendapatan, bblr dan penyakit infeksi sedangkan variabel dependen adalah kejadian stunting pada baduta usia $6-23$ bulan.

Pengumpulan data penyakit infeksi dalam 3 bulan terakhir yaitu diare dan ISPA baduta dilakukan dengan wawancara kuisioner terstruktur kepada ibu baduta dan rekam medik dari dokter puskesmas, sedangkan berat badan lahir rendah diperoleh dengan melihat buku KIA (Kesehatan Ibu dan Anak). Penentuan status gizi stunting baduta diperoleh melalui pengukuran panjang badan dengan metline. Pengukuran panjang badan dilakukan oleh peneliti dan 4 enumerator yang telah terlatih. Analisis data yang dilakukan menggunakan software SPSS 21 dengan uji Chi Square pada variabel independen karena data yang masuk dianggap dalam data yang berdistribusi normal dengan skala nominal dan ordinal serta uji OR digunakan untuk mengetahui besar risiko dari masing-masing variabel yang saling berhubungan dengan menggunakan uji statistik regresi logistik berganda pada tingkat kemaknaan 95\% 
$(\alpha=0.05)$. Penelitian ini telah disetujui oleh Komisi Etik Penelitian Kesehatan Fakultas Kesehatan Masyarakat Universitas Airlangga dengan nomor etik 484-KEPK.

\section{HASIL DAN PEMBAHASAN}

\section{Karakteristik Keluarga Subyek Penelitian}

Berdasarkan tabel 1. Sebagian besar baduta stunting berusia 19-23 bulan sedangkan baduta non stunting berusia 6-12 bulan. Sebagian besar baduta stunting dan non stunting berjenis kelamin laki-laki. Dari variabel usia dan jenis kelamin baduta tidak ada hubungan yang bermakna dengan kejadian stunting pada baduta dengan nilai p-value sebesar 0,227 untuk usia dan 1 untuk jenis kelamin. Hasil penelitian ini didukung dengan adanya pernyataan bahwa terdapat tiga penyebab yaitu penyebab langsung dari kejadian stunting yaitu asupan gizi yang kurang, penyakit infeksi, ketidaksesuaian penyapihan, dan berat badan lahir rendah sedangkan penyebab tidak langsung yaitu wanita yang mengalami malnutrisi, ketahanan pangan rumah tangga yang tidak memadai, pola asuh dan praktik pemberian makan yang tidak memadai, dan lingkungan yang tidak sehat serta pelayanan kesehatan yang tidak memadai.

Penyebab dasar masalah stunting diantaranya akses rumah tangga terhadap kuantitas dan kualitas sumber daya yang memadai seperti tanah, pendidikan,

Tabel 1. Distribusi Karakteristik baduta dan Karakteristik pendidikan, pekerjaan, dan pendapatan keluarga

\begin{tabular}{|c|c|c|c|c|c|}
\hline \multirow{2}{*}{ Variabel } & \multicolumn{2}{|c|}{ Kasus } & \multicolumn{2}{|c|}{ Kontrol } & \multirow{2}{*}{$p$-value } \\
\hline & $n$ & $\%$ & $\mathbf{n}$ & $\%$ & \\
\hline \multicolumn{6}{|l|}{ Pendidikan Kepala Keluarga } \\
\hline Pendidikan Rendah & 17 & 65,5 & 16 & 61 & \multirow{3}{*}{0,443} \\
\hline Pendidikan Menengah & 6 & 23 & 9 & 35 & \\
\hline Pendidikan Tinggi & 3 & 11,5 & 1 & 4 & \\
\hline \multicolumn{6}{|l|}{ Pendidikan Ibu } \\
\hline Pendidikan Rendah & 15 & 57,7 & 14 & 54 & \multirow{3}{*}{0,256} \\
\hline Pendidikan Menengah & 7 & 27,3 & 11 & 42 & \\
\hline Pendidikan Tinggi & 4 & 15 & 1 & 4 & \\
\hline \multicolumn{6}{|l|}{ Pekerjaan Kepala Keluarga } \\
\hline Guru & 1 & 4 & 1 & 4 & \multirow{6}{*}{0,484} \\
\hline Buruh & 6 & 23 & 3 & 11,6 & \\
\hline Petani & 2 & 7,7 & 2 & 7,7 & \\
\hline Wiraswasta & 15 & 57,7 & 19 & 72,7 & \\
\hline Staff desa & 0 & 0 & 1 & 4 & \\
\hline Pegawai Swasta & 2 & 7,7 & 0 & 0 & \\
\hline \multicolumn{6}{|l|}{ Status Pekerjaan Ibu } \\
\hline Bekerja & 7 & 27,3 & 1 & 4 & \multirow{2}{*}{0,055} \\
\hline Tidak Bekerja & 19 & 72,7 & 25 & 96 & \\
\hline \multicolumn{6}{|l|}{ Pendapatan (Sesuai UMK) } \\
\hline$<$ Rp. 2.042.900 & 21 & 19 & 24 & 92,3 & \multirow{2}{*}{0,416} \\
\hline$\geq$ Rp. 2.042 .900 & 5 & 81 & 2 & 7,7 & \\
\hline \multicolumn{6}{|l|}{ Jenis Kelamin } \\
\hline Laki-laki & 16 & 61,5 & 15 & 57,8 & \multirow{2}{*}{1} \\
\hline Perempuan & 10 & 38,5 & 11 & 42,2 & \\
\hline \multicolumn{6}{|l|}{ Usia } \\
\hline $6-12$ bulan & 8 & 30,8 & 11 & 42,2 & \multirow{3}{*}{0,227} \\
\hline 13-18 bulan & 5 & 19,2 & 8 & 30,8 & \\
\hline 19-23 bulan & 13 & 50 & 7 & 27 & \\
\hline
\end{tabular}

* Signifikan berdasarkan Chi-Square test dengan $\alpha=5 \%$ 
pekerjaan, pendapatan, teknologi yang disebabkan oleh sumber daya keuangan, manusia, fisik dan sosial yang tidak memadai dan penyebab paling mendasar dipengaruhi oleh sosial budaya, ekonomi, dan politik ${ }^{12}$. Kemungkinan penyebab tidak ada hubungan antara usia dan jenis kelamin dengan risiko stunting karena pada baduta belum terlihat adanya perbedaan kecepatan dan pencapaian pertumbuhan dari segi usia maupun jenis kelamin. Hal tersebut akan terlihat ketika memasuki usia remaja, dimana usia remaja merupakan puncak pertumbuhan dan dari segi jenis kelamin perempuan akan terlebih dahulu mengalami peningkatan kecepatan pertumbuhan daripada laki-laki ${ }^{16}$.

Pendidikan kepala keluarga untuk kelompok stunting dan non stunting sebagian besar memiliki tingkat pendidikan rendah. Pendidikan ibu baik kelompok stunting dan non stunting sebagian besar juga memiliki tingkat pendidikan rendah. Dari data tingkat pendidikan orang tua menunjukkan bahwa tidak ada hubungan dengan kejadian stunting pada baduta dengan nilai $p$-value sebesar 0,443 untuk pendidikan kepala keluarga dan 0,256 untuk pendidikan ibu.

Hasil hubungan yang tidak signifikan antara pendidikan ayah dan ibu terhadap baduta stunting di Desa Maron Kidul dikarenakan di daerah tersebut, akses terhadap pendidikan sebagai penunjang informasi terbilang sulit. Ini terlihat pada Tabel 1 dimana pendidikan ayah dan ibu terbilang pada baduta stunting maupun non stunting sebagian besar memiliki pendidikan rendah. Penelitian ini sejalan dengan penelitian yang mengatakan bahwa tingkat pendidikan orangtua tidak memiliki hubungan dengan kejadian stunting pada baduta di Kecamatan Balen Kabupaten Bojonegoro ${ }^{17}$.

Tingkat pendidikan bukan merupakan karakteristik yang dapat mempengaruhi stunting secara langsung karena masih banyak faktor-faktor lain yang dapat mempengaruhi terjadinya masalah kurang gizi. Namun, Ibu yang berpendidikan tinggi akan lebih baik dalam memahami informasi dan mampu belajar untuk mendapatkan pengetahuan terkait dengan pola asuh dan gizi baduta sehingga nantinya baduta dapat memiliki status gizi yang lebih baik ${ }^{18}$.

Seluruh kepala keluarga pada kelompok stunting dan non stunting sebagian besar bekerja sebagai wiraswasta, sedangkan pada ibu menunjukkan bahwa lebih banyak ibu yang memilih menjadi ibu rumah tangga pada kelompok non stunting daripada kelompok stunting. Dari data pekerjaan orangtua tidak ada hubungan dengan kejadian stunting pada baduta dengan nilai $p$-value sebesar 0,484 untuk pekerjaan ayah dan 0,055 untuk pekerjaan ibu. Meskipun tidak berhubungan namun baduta dengan ibu tidak bekerja lebih cenderung tidak stunting karena ibu yang tidak bekerja akan lebih memperhatikan kualitas dan kuantitas makanan yang nantinya dikonsumsi oleh anak dan juga memiliki lebih banyak waktu mengurus dan merawat anak, namun faktor lain juga perlu diperhatikan seperti tingkat pengetahuan dan pola asuh ibu ${ }^{19}$.

Kategori pendapatan disesuaikan
dengan Upah Minimum Kabupaten Probolinggo (UMK) yaitu sebesar Rp. 2.042.900. Pada kelompok stunting keluarga yang memiliki pendapatan dibawah UMK sebesar 92,3\%sedangkan pada kelompok non stunting yang memiliki pendapatan dibawah UMK yaitu sebesar $81 \%$. Berdasarkan hasil analisis Chi-Square menunjukkan bahwa pendapatan tidak ada hubungan dengan stunting dengan nilai $\mathrm{p}$-value sebesar 0,416. Meskipun pendapatan tidak berhubungan dengan stunting, namun pendapatan yang dimiliki oleh keluarga stunting lebih banyak yang dibawah UMK dibandingkan dengan kelompok yang non stunting.

Pendapatan dapat mencerminkan tingkat kemampuan keluarga dalam konsumsi makanan dan pola asuh keluarga terhadap anak yang dapat mengakibatkan risiko mengalami berat badan lahir rendah dan penyakit infeksi semakin besar.

Sebagian besar anak baduta yang mengalami gangguan pertumbuhan memiliki status ekonomi relative rendah ${ }^{20}$. Data menunjukkan bahwa adanya kejadian stunting pada baduta sebagian besar disebabkan karena tingkat pendapatan dan pendidikan orang tua yang rendah. 
Tabel 2. Hubungan Berat badan Lahir Rendah dan Penyakit Infeksi dengan Kejadian Stunting pada Baduta

\begin{tabular}{lcccccc}
$\begin{array}{l}\text { Variabel yang } \\
\text { diteliti }\end{array}$ & \multicolumn{2}{c}{ Stunting } & \multicolumn{2}{c}{ Non stunting } & p-value & OR (Cl: 95\%) \\
\cline { 2 - 5 } & $\mathbf{n = 2 6}$ & $\%$ & $\mathbf{n = 2 6}$ & $\%$ & & \\
\hline $\begin{array}{l}\text { Berat Badan Lahir } \\
\quad \text { Rendah }\end{array}$ & 9 & 34,6 & 2 & 7,7 & $p=0,042$ & $0,157(0,030-0,822)$ \\
$\quad$ Normal & 17 & 65,4 & 24 & 92,3 & & \\
\hline $\begin{array}{l}\text { Penyakit Infeksi } \\
\quad \text { Sakit }\end{array}$ & 15 & 58 & 7 & 27 & $p=0,049$ & $3,071(1,155-11,861)$ \\
$\quad$ Tidak sakit & 11 & 42 & 19 & 73 & & \\
\hline
\end{tabular}

Lalu rendahnya status ekonomi dari sebuah keluarga dapat memiliki dampak yang buruk pada pertumbuhan anak yaitu kemungkinan anak menjadi kurus dan pendek $^{21}$. Keluarga dengan status ekonomi baik bisa mendapatkan pelayanan yang lebih baik seperti pelayanan kesehatan, aksesbilitas jalan, dan pendidikan sehingga akan berdampak positif terhadap status gizi anak ${ }^{21}$.

\section{Berat badan lahir pada Baduta}

Berdasarkan tabel 2, diketahui bahwa hasil penelitian menunjukkan baduta stunting dan non stunting sebagian besar memiliki berat badan lahir normal. Hasil uji statistika chisquare menunjukkan bahwa ada hubungan berat badan lahir baduta dengan stunting dengan nilai $p$-value sebesar $p=0,042$ yang memiliki arti bahwa ada hubungan berat badan lahir rendah pada baduta stunting dan non stunting. Lalu diperoleh nilai OR (Odds Ratio) sebesar 0,157 (95\% Cl: 0,030-0,822), Nilai OR memiliki arti bahwa anak baduta yang memiliki riwayat BBLR 0,157 kali lebih besar berisiko mengalami stunting dibandingkan dengan baduta yang tidak mengalami BBLR.

Hasil bblr dengan hasil odds ratio rendah dikarenakan jumlah baduta stunting dan non stunting sebagian besar memiliki berat badan normal meskipun jumlah baduta stunting lebih banyak yang mengalami bblr (35\%) dibandingka baduta non stunting (8\%). Hal ini dapat disebabkan karenastatus ekonomi keluarga, dari hasil penelitian ditemukan orang tua baduta stunting memiliki tingkat penghasilan golongan kurang dari UMK daripada non stunting yaitu sebesar $92,3 \%$. Status ekonomi keluarga dapat mempengaruhi status gizi ibu saat hamil, dimana status gizi ibu saat hamil akan mempengaruhi status gizi janin. Status ekonomi mempengaruhi kemampuan orang tua dalam membeli dan mendapatkan makanan yang bernilai gizi tinggi, beberapa studi mengatakan bahwa pendapatan merupakan faktor yang sangat mempengaruhi kemampuan dalam memilih kualitas dan kuantitas makanan ${ }^{22}$.

Gizi diperlukan dalam mendukung mekanisme biologis dan kimiawi dalam tubuh termasuk dalam otak ${ }^{23}$. Faktor lain yang dapat mempengaruhi kejadian BBLR adalah tingkat pendidikan. Hasil penelitian menunjukkan bahwa orangtua baduta stunting memiliki pendidikan rendah. Ibu dengan tingkat pendidikan rendah memiliki peluang 12 kali lebih besar melahirkan bayi dengan berat lahir rendah ${ }^{24}$. Selain itu penelitian lain menyatakan bahwa pada berat badan lahir yang rendah merupakan salah satu faktor yang mempengaruhi pertumbuhan linear balita.

Penelitian tersebut menjelaskan bahwa kondisi lingkungan pra kelahiran yaitu berat badan saat lahir lebih berpengaruh terhadap pertumbuhan linear daripada faktor pasca kelahiran ${ }^{25}$. Lalu penelitian lain menyatakan bahwa BBLR merupakan faktor risiko yang paling besar terkait dengan kejadian stunting dan memiliki risiko 5,87 kali untuk mengalami stunting di wilayah Puskesmas Sungai Karias, Hulu Sungai Utara ${ }^{26}$.

\section{Penyakit Infeksi pada Baduta}

Berdasarkan tabel 2, hasil penelitian menunjukkan mayoritas baduta stunting memiliki penyakit infeksi terdapat 58\% dalam 3 bulan terakhir, sedangkan mayoritas baduta non stunting terdapat $73 \%$ tidak mengalami sakit dalam tiga bulan terakhir. 
Hasil uji statistika chi-square pada baduta stunting dan non stunting diketahui bahwa $p=0,049$ yang memiliki arti bahwa ada hubungan status penyakit infeksi pada baduta stunting dan non stunting. Selain itu, diperoleh nilai OR (Odds Ratio) sebesar 3,071 (95\% Cl: 1,155 - 11,861). Nilai OR memiliki arti bahwa anak baduta yang memiliki penyakit infeksi dalam 3 bulan terakhir 3,071 kali lebih besar berisiko mengalami stunting dibandingkan dengan baduta yang tidak mengalami penyakit infeksi. Penelitian ini sejalan dengan penelitian yang menyatakan bahwa balita yang memiliki riwayat infeksi penyakit diare dan ISPA lebih berisiko mengalami stunting yaitu 4,808 kali lebih besar daripada balita yang tidak mengalami riwayat infeksi penyakit ${ }^{19}$.

Praktik higiene yang buruk dapat menyebabkan munculnya bakteri. Bakteri dapat masuk melalui makanan yang biasa disajikan dapat berpengaruh terhadap kesehatan anak tersebut, salah satunya timbul penyakit diare dan dapat menyebabkan anak kehilangan cairan serta sejumlah zat gizi yang esensial bagi tubuh ${ }^{27}$. Seorang anak yang terkena diare akan mengalami malabsorbsi zat gizi dan durasi diare yang berlangsung lama (lebih dari empat hari) akan membuat anak semakin mengalami kehilangan zat gizi, bila tidak segera ditangani dengan asupan yang sesuai maka dapat terjadi gagal tumbuh ${ }^{28}$. Diare yang terjadi dalam dua tahun pertama kehidupan dapat berpengaruh terhadap terjadinya retardasi pertumbuhan ${ }^{29}$. Anak yang kurang gizi akan memiliki daya tahan tubuh terhadap penyakit yang rendah sehingga terkena penyakit infeksi seperti diare dan ISPA sehingga mempengaruhi perkembangan kognitif anak dan menghambat pertumbuhan $^{30}$.

\section{KESIMPULAN}

Hasil penelitian menunjukkan bahwa penyakit infeksi diare dan ISPA dalam 3 bulan terakhir serta berat badan lahir rendah merupakan faktor penyebab stunting pada baduta. Penyakit infeksi merupakan faktor terbesar penyebab stunting yaitu baduta dengan penyakit infeksi 3,071 kali lebih besar berisiko mengalami stunting dibandingkan dengan baduta yang tidak mengalami penyakit infeksi. Berat badan lahir rendah memiliki hubungan namun memiliki risiko yang rendah yaitu baduta dengan berat badan lahir rendah 0,157 kali lebih besar berisiko mengalami stunting dibandingkan dengan baduta yang memiliki berat badan lahir normal. Disarankan untuk baduta yang memiliki masalah BBLR dan penyakit infeksi diberikan perhatian khusus oleh posyandu serta perlu dilakukan peninjauan terkait perkembangan secara rutin agar gangguan perkembangan yang mungkin terjadi dapat segera dikenali dan diatasi.

\section{ACKNOWLEDGEMENT}

Ucapan terimakasih diberikan penulis kepada responden dan seluruh instansi yang telah membantu kelancaran selama penelitian dilakukan serta seluruh staf dan pengajar Program Studi Gizi FKM Universitas Airlangga khususnya dosen pembimbing atas pengarahan yang diberikan.

\section{REFERENSI}

1. Direktorat Gizi Masyarakat. Kementerian Kesehatan Republik Indonesia. Rencana Strateg. Kementeri. Kesehat. tahun 2015-2019 248 (2015). doi:351.077

2. World health statistics. Monitoring Health for the SDG's. (World Health Organization, 2016).

3. Direktorat Gizi Masyarakat. Hasil Pemantauan Status Gizi. (Kementerian Kesehatan Republik Indonesia, 2016). doi:10.1080/14783363.2011.637802

4. Sekretariat Wakil Presiden RI. 100 Kabupaten/kota prioritas untuk intervensi anak kerdil (stunting). 1, (2017).

5. Dinas kesehatan Probolinggo. Profil Kesehatan Kabupaten Probolinggo tahun 2016. (Dinas Kesehatan Probolinggo, 2016).

6. Amin, N. A. \& Julia, M. Faktor Sosiodemografi dan Tinggi Badan Orangtua serta Hubungannya dengan Kejadian Stunting pada Balita Usia 6-23 Bulan. J. Gizi dan Diet. Indones. 2, 171 (2014).

7. Devriany, Wardani, Z. \& Yuniar. The Differences of Exclusive Breastfeeding 
for Neonates Length. Indones. J. Public Heal. 14, 44-51 (2018).

8. Santos, I. S. et al. Late preterm birth is a risk factor for growth faltering in early childhood: A cohort study. BMC Pediatr. 9, 1-8 (2009).

9. Proverawati, A. \& Ismawati, C. Berat Badan Lahir Rendah. (Nuha Medika, 2010).

10. Nurillah, A., Kencana, S. \& Indri Yunita, S. Panjang Badan Lahir Pendek Sebagai Salah Satu Faktor Determinan Keterlambatan Tumbuh Kembang Anak Umur 6-23 Bulan Di Kelurahan Jaticempaka, Kecamatan Pondok Gede, Kota Bekasi. J. Ekol. Kesehat. 15, 3-9 (2016).

11. The World Bank. Nutritional Failure in Ecuador. World Bank Country Study (2007). doi:10.1596/978-0-8213-7019-3

12. UNICEF. Improving Child Nutrition - The achievable imperative for global progress. United Nations Children's fund. (2013). doi:978-92-806-4686-3

13. Richard, S. A. et al. Diarrhea in early childhood: Short-Term association with weight and long-Term association with length. Am. J. Epidemiol. 178, 11291138 (2013).

14. Elyana, M. \& Candra, A. Hubungan frekuensi ISPA dengan status gizi balita. 78, 1-12 (2009).

15. Lestari, W., Margawati, A. \& Rahfiludin, M. Z. Stunting risk factors in children aged 6-24 months in Penanggalan sub district Subulussalam city of Aceh Province. J. Nutr. Indones. 3, 37-45 (2014).

16. Mar'atussalehah, A. \& Bardosono, S. Prevalensi Anak Berisko Stunting dan Faktor-faktor yang Berhubungan : Studi Cross Sectional pada anak usia 3-9 tahun di Pondok Pesantren Tapak Sunan Condet pada tahun 2011 The Prevalance of Children with Stunting Risks and Its Related Factors : a crossect. 1-10 (2011).

17. Solehan, L. F. dan M. of Nutrition College - Volume 2 Nomor 4 Tahun 2013 Halaman 523-530. J. Nutr. Coll. 1, 127133 (2012).

18. Lailatul, M. \& Ni'mah., C. Hubungan Tingkat Pendidikan, Tingkat
Pengetahuan dan Pola Asuh Ibu dengan Wasting dan Stunting pada Balita Keluarga Miskin. Media Gizi Indones. 10, 84-90 (2015).

19. Chamilia, D. \& Nindya, T. S. Hubungan Riwayat Penyakit Diare dan Praktik Higiene dengan Kejadian Stunting pada Balita Usia 24-59 Bulan di Wilayah Kerja Puskesmas Simolawang, Surabaya. Amerta Nutr. 1, 243-251 (2017).

20. Illahi, R. . Hubungan pendapatan keluarga, berat lahir, dan panjang lahir dengan kejadian. 3, 1-14 (2017).

21. Bishwakarma, R. \& Vanneman, R. D. Spatial Inequality in Child Nutrition: Implications of Regional Context and Individual/Household Composition. Disertasi Univ. Maryland, Coll. Park 119140 (2011).

22. Sediaoetama, A. . Ilmu gizi untuk mahasiswa dan profesi. (PT.Dian Rakyat, 2010).

23. Delemarre-van de Waal, H. A. Environmental factors influencing growth and pubertal development. Environ. Health Perspect. 101, 39-44 (1993).

24. Khairina \& Modjo, R. Faktor-faktor yang Berhubungan dengan Kejadian Bayi Berat Lahir Rendah ( BBLR) di Wilayah Kerja Puskesmas Kecamatan Cipayung Kota Depok Provinsi Jawa Barat Tahun 2013. Dep. K3 Fak. Kesehat. Masy. Univ. Indones. 1-16 (2013). doi:10.1109/iihmsp.2015.42

25. Briawan, D. \& Drajat Martianto, D. Faktor Risiko Stunting Pada Anak Usia 0-23 Bulan Di Provinsi Bali, Jawa Barat, Dan Nusa Tenggara Timur (Risk Factors of Stunting among 0-23 Month Old Children in Bali Province, West Java and East Nusa Tenggara). J. Gizi dan Pangan ISSN 1978, 125-132 (2014).

26. Rahayu, A. \& Yulidasari, F. Riwayat Berat Badan Lahir Rendah dengan Kejadian Stunting pada Baduta. 67-73 (2015). doi:10.21109/kesmas.v10i2.882

27. Welasih, B. . \& Wirjatmadi, B. Beberapa faktor yang berhubungan dengan status gizi balita stunting. Tanaffos 11, 12-17 (2012).

28. Weisz, A. et al. The duration of diarrhea 
and fever is associated with growth faltering in rural Malawian children aged 6-18 months. Nutr. J. 10, 25 (2011).

29. Batiro, B., Demissie, T., Halala, Y. \& Anjulo, A. A. Determinants of stunting among children aged 6-59 months at Kindo Didaye woreda, Wolaita Zone, Southern Ethiopia: Unmatched case control study. PLoS One 12, 1-15 (2017). 30. Wellina, W. F., Kartasurya, M. I. \& Rahfilludin, M. Z. Faktor risiko stunting pada anak umur 12-24 bulan. J. Gizi Indones. (ISSN 1858-4942) 5, 55-61 (2016). 